\title{
Policy Trilemma and Interest Rate Behaviour in Nigeria
}

\begin{abstract}
Korede Ajogbeje $^{1}$, Oluwatosin Adeniyi ${ }^{2}$ and Festus O. Egwaikhide ${ }^{3}$ Policy makers face trade-off in dealing with exchange rate management, monetary independence and concerns about capital mobility simultaneously. This study empirically examines the effects of Nigeria's trilemma policy path on interest rate using data spanning from 1997:Q1 to 2017:Q3. It equally incorporates the role of external reserves in buffering these effects. Stationarity of the series were ascertained with Zivot-Andrew (ZA) structural break unit roots test technique, while the bounds test cointegration approach was used to confirm the cointegrating properties of the variables. We found that capital mobility has significant effect on interest rate in the long run baseline model and could also be successfully buffered with external reserves to reduce interest rate. Additionally, our results show that although exchange rate stability and monetary independence do not independently affect interest rate, but their interaction with external reserves does. This implies that external reserve serves as an effective buffer if appropriately employed by the monetary authorities. The trilemma policy can be used to optimally reduce interest rate. Also, external reserves could serve as a tool for economic stabilization with appropriate combination with other relevant policy variables.
\end{abstract}

Keywords: Capital Mobility, Exchange Rate Stability, Interest Rate, Monetary Independence, Trilemma Policies

JEL Classification: E4, E6, F4, F41.

DOI: $10.33429 /$ Cjas.09218.2/6

\subsection{Introduction}

Macroeconomic policies are made in such a way that their implementation will drive home the policy targets. This points to the importance of policy making in economic management, as it serves as a middle ground between goals and targets. A number of countries would want to have it all at their fingertips, i.e., to possess as much power as possible to have an overall policy control so as to drive

\footnotetext{
${ }^{1}$ Lagos Business School, Pan-Atlantic University, Nigeria

${ }^{2}$ Corresponding author: Department of Economics, University of Ibadan, Ibadan, Nigeria; saino78@yahoo.com; +234807033275062.

${ }^{3}$ Department of Economics, University of Ibadan, Ibadan, Nigeria
} 
economic variables. There are three core policy handles in macroeconomics and finance framework - the exchange rate system (ERS), monetary independence (MI) and capital mobility $(\mathrm{CM})$ - all of which have their various impacts on economic variables. However, policy makers typically face a trilemma trade-off whereby they can take full control of only two of these three policies at a given time (Pilbeam, 2006). In light of existing literature, cross country and country specific studies alike have also proved this theory to be right (Prasad et al., 2003, Obsfield et al, 2004, 2010., Hsing, 2012). Thus, there is a trilemma problem as countries are unable to take full control of these economic policies simultaneously.

The literature on the issue of the trilemma policy has attracted the attention of some economists, and most of the few extant studies are either panel analysis of regional scope or country specific in orientation. Previous studies have also produced divergent results as to the impacts of the trilemma indices on some macroeconomic aggregates (Aizenman et al., 2008; 2009; Hsing, 2012). Most of these studies related the trilemma policies with output volatility, growth and inflation volatility. This study deviates from the convention to study the impacts of these three policies on interest rate, which is an indicator of economic stability and at the same time a key determinant of investments. This falls in line with Hosny et al. (2015) position that the trilemma policies explain a sizeable proportion of the movement in domestic interest rates.

In the specific case of Nigeria which has in its more recent history been under diverse forms of managed float exchange rate regimes, with her financial borders open and appreciable monetary policy independence, at least two pertinent questions ensue, namely: what has been the effect of these policy combinations on interest rate in Nigeria?; and does external reserve play any intermediate role in complementing Trilemma policies? This study therefore broadly examines the reactions of interest rate in the presence of exchange rate flexibility, monetary independence and capital mobility in Nigeria.

The rest of this study is organised as follows: section 2 presents the review of relevant literature, while the methodology is presented in section 3. Presentation and 
discussion of the findings are presented in section 4 while in section 5 conclusion is made and some policy implications are given.

\subsection{Literature Review}

\subsection{Theoretical Framework}

The theoretical underpinning of this research is based on the Mundell-Fleming model (hereafter regarded as MFM) by Robert Mundell and Marcus Fleming, which is the dominant policy paradigm for studying the monetary and fiscal policy in an open economy. The MFM is an open economy version of the popular IS-LM model closed economy model. The MFM assumes that the economy is a small open economy with perfect capital mobility, which can be said that the economy embraces both trade and financial liberalization, thus the local interest rate is determined by the international prevailing interest rate. Mathematically represented by $r=r^{*}$, where $r$ and $r^{*}$ are the local and international interest rates, respectively. In this regard, the behaviour of the economy is dependent on the exchange rate system adopted by the nation.

\section{The Mundell-Fleming under a Floating Exchange Rate System}

Under a floating exchange rate system, the exchange rate is set by the market forces and is adjusted to achieve equilibrium in the money and goods market. The effects of an expansionary fiscal policy will shifts the IS curve to the right thus appreciating the exchange rate while income level remain the same. This is depicted by Figure 1. The effect of an expansionary monetary policy will raise income and reduce exchange rate, as depicted by Figure 2. Thus, under a floating exchange rate system, the monetary policy tends to be effective. A trade policy, say to reduce import through tariff or quota will increase the net export, which will thus change the IS curve by shifting it to the right while the LM curve remains constant. The effects of such a policy is also similar to that of the fiscal expansion as displayed in Figure 1. 


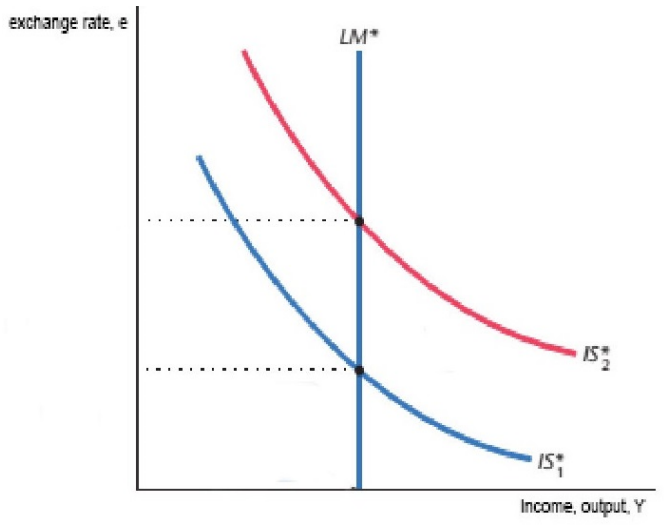

Figure 1: Fiscal Policy

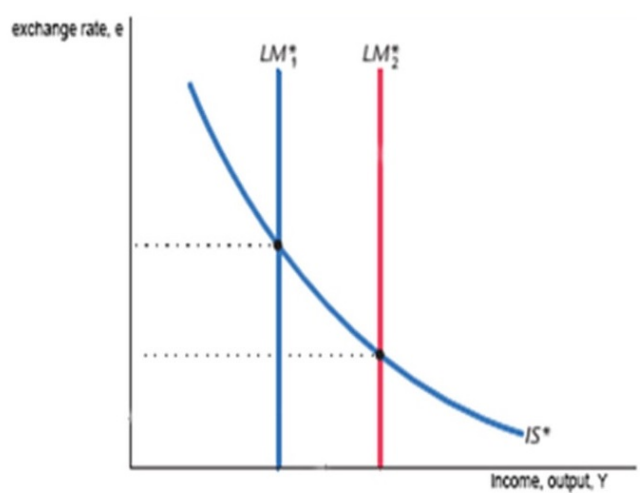

Figure 2: Monetary Policy

\section{The Mundell-Fleming under a Fixed Exchange Rate System}

The Bretton woods system embraces the fixed exchange rate which was adopted by major world economies in the 1950s and 1960s, but was abandoned in the 1970s to embrace the floating exchange rate system. Under the fixed exchange rate system, an expansionary fiscal policy will lead to an increase in savings and investment, thereby pressuring the market exchange rate upward (Figure 3). But because the policy maker is committed to fix the exchange rate, arbitragers quickly responds by selling foreign currency to the central bank in exchange for local currency, this will push up the sale of foreign currency for a local one, thus leading to monetary expansion by increasing the liquidity preference and money supply, which ultimately leads to an increase in output while exchange rate is still the same. Applying expansionary monetary policy under this exchange rate regime will increase the liquidity preference and money supply, thus leading to the appreciation of the local currency. The currency appreciation will force the public to sell domestic currency to the central bank and thereby lead to the returning of the liquidity preference and money supply to its initial position (Figure 3). Leading to the conclusion that monetary policy is ineffective under the fixed exchange rate. Therefore, opting for the fixed exchange rate, the central bank must give up its control of monetary policy.

The concise conclusion here is that, the exchange rate regime is the determinant of the ability of the monetary and fiscal policy to influence aggregate income. Embracing a fixed exchange rate will make the monetary authorities give up their 
monetary independence but will still be left with the option of using their capital mobility option (Figure 4).

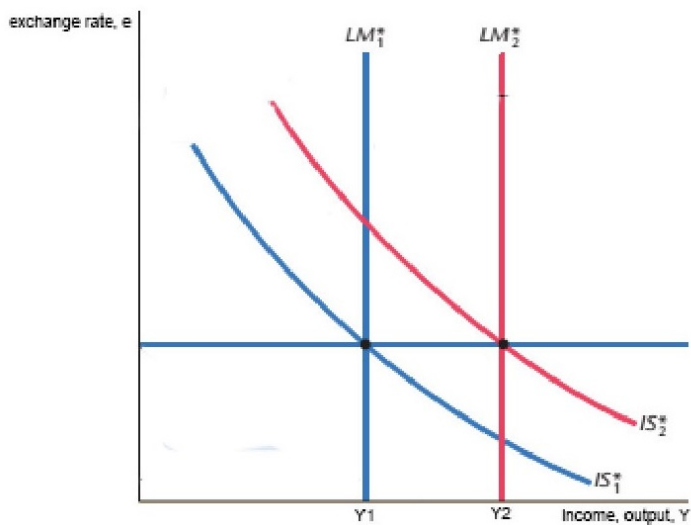

Figure 3: Fiscal and Monetary Policy

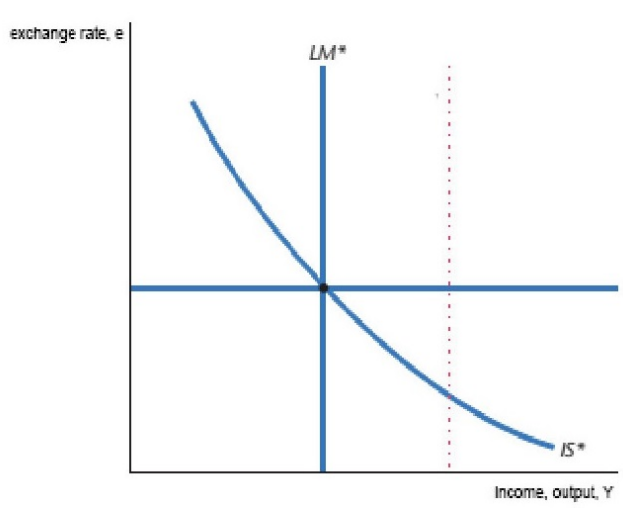

Figure 4: Equilibrium

\section{The Trilemma Policy}

The concept of the trilemma policy is one of the dominant issues in international macroeconomics. It is also known as the impossible trinity, meaning that it is impossible for an economy to have perfect capital mobility, independent monetary policy and at the same time operate a fixed exchange rate system. It must choose two out of the three and give up one. A trade-off must occur, which serves as a constraint to monetary policy makers. For instance, countries in the European zone have embraced the stability of their exchange rate and also allowed perfect capital mobility, thus they have surrendered their monetary policy decisions to the dictates of the European Central Bank (ECB). The United States of America (USA) chooses to allow perfect capital mobility and at the same time possess monetary independence leaving exchange rate to be strictly driven by market forces. A third case is China which prefers to pursue stability of the exchange rate and monetary independence while restrictions are placed on capital mobility (Pilbeam 2006, Mankiw 2010, Hsing, 2012).

Findings by Obstfeld et al (2004) reveal that the trilemma can be used as a macroeconomic policy framework. This also conforms to the statement of Aizenman (2013) that 'the extended trilemma framework keeps providing useful insights 
about the trade-offs and challenges facing policy makers, investors, and central banks'. Thus, pointing to the fact that the trilemma can be enshrined in deciding the policy framework of a nation. As direct as this policy appears to be, some policy makers tend not to pay rapt attention to it. This is perhaps due to few empirical proofs to back up the policy trade-offs. This can, however, be linked to the challenges in the measurements of the three components involved in the policy.

Recently, however, in order to avoid the consequences of the extremes, emerging economies have converged towards the intermediate level of all the three trilemma indices (Aizeman et al., 2008; Aizenman and Ito, 2012), meaning that there is an optimal combination of managed exchange rate flexibility, controlled financial integration and monetary independence.

In addition, Aizenman et al (2008) opine that "while the original framing of the trilemma was silent regarding the role of reserves, recent trends suggest that reserve accumulation may be closely related to changing patterns of the trilemma especially for developing countries'. This can be backed up with the fact that countries with monetary policy independence and absolute capital mobility tend to experience higher exchange rate volatility. If such a country experiences a depreciation of currency, the depreciation can be mitigated by using the nation's external reserve (RES) to buy local currency in the foreign exchange market. Likewise, if the country is experiencing an appreciation of its domestic currency, it can be stabilised by selling domestic currency in the foreign exchange market. Therefore, a country's external reserves can serve as a buffer to the trilemma trade-offs. This realisation has made external reserve relevant to the study of the trilemma policy.

\subsection{Empirical Literature}

Scholars have studied the trilemma policies in relation to diverse issues around it, both in the country specific and cross-country dimensions. However, besides Herwartz and Roestel (2017) who studied twenty developed nations and found that transmission of interest rate is a nonlinear positive function of financial openness and foreign exchange stability, most of the empirical studies in this regard are crosscountry in dimension, which cut across both developing and developed economies. 
These studies are thus reviewed by first discussing studies on the trilemma policy in relation to developing and emerging economies, and then delve into others that studies both developing and developed economies.

\section{Developing and emerging Economies}

A country specific study focused on China was done by Glick and Hutchison (2008). They used a vector error correction model (VECM) on data spanning the first quarter of 1992 and the fourth quarter of 2007 to check the impact of the nation's trilemma on monetary policy in the wake of the liberalisation of China's goods and financial markets. Their results revealed that when there is rapid foreign exchange reserve accumulation and limited exchange rate flexibility, there is a rapid inflation increase in the face of limited effectiveness of sterilization. The trilemma was, however, not binding when there is a sharp decline in the level of economic activities.

Hsing (2012) investigated how the trilemma policies affected inflation, growth volatility and interest volatility in Bulgaria. The evidence showed that the combined policies had no effect on the target variables, related to the general price level, while they had a mixture of both positive and negative significant effects on growth volatility.

Obstfeld (2014) used correlation and panel regression techniques in evaluating the capacity of emerging nations to moderate the impact of global monetary shocks through the channel of their domestic financial system. The author found that economies that are able to embrace flexible exchange rate system perform better than their counterparts who prioritise monetary independence at the expense of exchange rate flexibility. He also showed that financial globalization had a downside for economic management, as it worsened the trade-offs faced by monetary policy in choosing among multiples domestic macroeconomic objectives.

The trilemma policy mix has changed over time in India as found by Majumder and Nag (2017). The authors made use of quarterly data between 1991 and 2015, and found that in the long run, the trilemma policy constraint is binding, but there 
is a deviation from the constraint in the short run. The study further found that factors that determines the trilemma efficiency includes; financial development, central bank intervention, financial stress, and the economy's liquidity. Inflation rate is significantly reduced by higher monetary independence, and capital account openness and exchange rate stability are linked to larger output gap and higher growth rate.

Law (2017) empirically tested the hypothesis that trilemma policy convergence of emerging nations is influenced by external reserves. Using a threshold model, the author tested this hypothesis by studying the relationships among international reserves, policy dispersion and trade openness. The study found that when the external reserve is above a certain threshold, it will be significant in achieving policy conversion or policy dispersion. This, therefore, concludes on the need to hold a sufficient level of external reserves in order for it to be effective.

Employing the portfolio balance model, Akinkunmi (2017) tested for the trilemma constraint in 30 emerging markets and also investigates the role of exchange rate intervention on the constraint. The result shows that the trilemma constraint is evident in these markets as a whole, and also in the African emerging market. The constraint was, however, not found in the sample of non-African emerging economies. In addition, the study reveals that tightening of the constraint is not significantly influenced by the foreign exchange intervention.

\section{Developing and Developed Economies}

Shambaugh (2003) studied the effect of fixed exchange rates on monetary policy and classified the countries into pegged and non-pegged. He used cointegration analyses and found that despite the widespread notion that all countries lack monetary freedom, the evidence indicated that pegged countries follow base country interest rate than non-pegged countries.

Obsfield et al (2004) examined the historical trade-offs among the trilemma indices. They argued that the overall evidence supports a modified view of the trilemma in the modern era. Specifically, they found that monetary autonomy is 
clearly affected by the exchange rate regime and capital controls, but when floating exchange rate was combined with capital controls, it resulted to an unfettered autonomy.

Aizenman et al (2008) attempted to validate the trade-off between the trilemma variables and came up with a number of conclusions. First, pursuing monetary independence leads to dampened output volatility, while the embrace of exchange rate stability makes output more volatile. Second, combining stable exchange rate with medium level of financial development can increase output volatility. Third, they however reported that the availability of high level of financial development with greater financial openness can reduce output volatility. However, a net inflow of portfolio investment and unstable bank lending rate can increase output volatility.

A study that looked at the convergence pattern of the trilemma policies and the volatility of output by Aizenman and Ito (2012) between regional country groups found that the three dimensions of the trilemma policy of emerging nations had converged to a middle ground. In their view, emerging markets with more control over trilemma policy convergence experienced lower output volatility. They further pointed the role of the ratio of international reserves to GDP, since emerging countries with relatively low reserves level were prone to experiencing a higher level of output volatility.

In a study of the Central and Eastern Europe (CEE) economies, Ihnatov and Capraru (2014) used the Newey-West methodology on the trilemma index built by Aizenman et al (2012) to test the implication of the trilemma policies on the volatility of output and inflation. Their results showed that capital mobility had a significant impact in reducing macroeconomic volatility, while the same could not be concluded for the other two indices, namely - monetary independence and exchange rate stability.

Ito and Kawai (2014) studied the determinants of trilemma policy combination in an extensive sample of 78 countries. They discovered that the trilemma con- 
straint was binding. Equally, they found that when a currency, banking or debt crisis breaks out, policy combination happens to violate the trilemma constraint, suggesting that the deviation from the trilemma policy will result in policy stress which would manifest in crises unless the policy combination is adjusted to conform to the trilemma constraint.

Hosny et al (2015) test the trilemma hypothesis on a set of developing and developed nations during the gold standard period, the Bretton woods periods and the post-Bretton Woods period. They focused attention on the path of monetary independence over time and the dynamics of domestic interest rates in connection with the base country's interest rate. They also looked into the speed of adjustment of interest rates in the home country to disequilibrium in interest rate in the base country. They found that exchange rate regimes and capitals control affected monetary independence. Their results also showed that volatility of domestic interest rate is more pronounced in the non-pegged periods than pegged periods.

As evident in literature, most studies on trilemma policies relate to output volatility, growth and inflation volatility. This study, therefore, treads a distinct path by examining the effects of these policies on interest rate, using quarterly data. This is imperative since interest rate is an economic stability variable, and at the same time major determinant of investment. Lower (higher) interest rate will help increase (reduce) output through the investment channel. In addition, previous authors studied the trilemma effects without accounting for how external reserves could mitigate policy constraints.

\subsection{Methodology}

\subsection{Model Specification}

The model specification of this study is founded on both the theoretical framework and arguments by other relevant studies in the literature. Theoretically, the trilemma policy suggests the impossibility of simultaneously handling three key variables in an open macroeconomy. In order to assess the implication of Nigeria's trilemma policy mix on interest rate in the country, we introduced a model that uses a measure of combination of these variables in consonance with the treatment 
in Capraru and Ihanatov (2014), and Hsing (2012). This is compactly represented in equation (1) as follows:

$$
\mathrm{Y}_{\mathrm{t}}=g\left(E R S_{t}, M I_{t}, C M_{t}\right)
$$

Taking the natural logarithm of equation (1) yields:

$$
\operatorname{LnY}_{\mathrm{t}}=\alpha+\beta L n E R S_{t}+\gamma \operatorname{LnM} I_{t}+\delta L n C M_{t}+\varepsilon_{t}
$$

In principle, the dynamics of the trilemma can be tied to reserve accumulation (Aizenman et al., 2008). This justifies the addition of reserves to the model in its own right, and its subsequently multiplicative interaction with the trilemma variables. Therefore, the augmented version of equation (2) becomes:

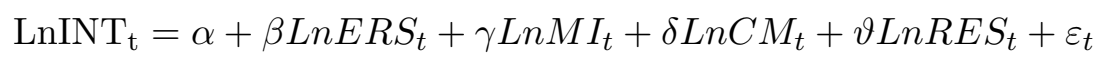

Equation 3 serves as the base model. The interactive models or buffer models are given in equations (4) to (6).

$$
\begin{aligned}
& \operatorname{LnINT}_{\mathrm{t}}=\alpha+\beta L n E R S_{t}+\gamma L n M I_{t}+\delta L n C M_{t}+\vartheta\left(\ln E R S^{*} L n R E S\right)_{t}+\varepsilon_{t} \\
& \operatorname{LnINT}_{\mathrm{t}}=\alpha+\beta \operatorname{LnER} S_{t}+\gamma \operatorname{LnM} I_{t}+\delta L n C M_{t}+\vartheta\left(\ln M I^{*} \operatorname{LnRES}\right)_{t}+\varepsilon_{t} \\
& \operatorname{LnINT}_{\mathrm{t}}=\alpha+\beta \operatorname{LnERS_{t}}+\gamma \operatorname{Ln} M I_{t}+\delta \operatorname{LnC} M_{t}+\vartheta\left(\ln C M^{*} \operatorname{LnRES}\right)_{t}+\varepsilon_{t}
\end{aligned}
$$

where: $I N T$ is interest rate, $E R S$ is exchange rate stability, $M I$ is monetary independence, $C M$ is capital mobility and $R E S$ is external reserve.

For ease of interpretation, the measurements of the indices are constructed through the computations provided in Appendix A.

\subsection{Estimation Techniques and Procedures}

The variables are subjected to a number of tests to ensure that the estimated results and conclusions are realistic, efficient and stable. These tests are precisely unit roots and cointegration. The estimable model is also specified in its long-run and short-run formats. We subsequently describe each of these phases in turn. 


\section{Unit Roots Tests:}

Stationarity properties of a series are revealed through unit root testing. For accuracy and reliability, the Zivot-Andrew unit root test was employed. This test incorporates the possibilities of a structural break in the series. The underlying model of the test is:

$$
\Delta y_{t}=c+\sigma y_{t-1}+\theta t+\vartheta_{1} D U_{t}+\mu_{1} D T_{t}+\sum_{j=1}^{k} d_{j} \Delta y_{t-j}+\varepsilon_{t}
$$

In the model, the first difference operator is represented by $\Delta$, and the white noise error term is represented by $\varepsilon_{t}$. $\Delta y_{t-j}$ allows for serial correlation and makes sure the error term is white noise. The indicating dummy variable for a mean shift occurring at the time of break (TB) is represented by $D U_{t}$, while $D T_{t}$ is the corresponding trend shift variable. Here,

$$
D U_{t}= \begin{cases}1, & \text { if } t>T B \\ 0, & \text { otherwise }\end{cases}
$$

and

$$
D T_{t}= \begin{cases}\mathrm{t}-\mathrm{TB}, & \text { if } t>T B \\ 0, & \text { otherwise. }\end{cases}
$$

The null hypothesis $H_{0}: c=0$ states that the series tested is non-stationary with drift excluding structural change, while the alternative hypothesis $H_{1}: c<0$ states that the series in question is trend stationary which includes a one-time breakpoint.

\section{Cointegration Test and Estimation}

Cointegration tests examine the possibility of a long run relationship among nonstationary series. In the case where all the variables are $I(1)$, i.e, variables that are stationary at first difference, the Engle-Granger (E-G) and Johansen cointegration techniques are appropriate to capture the possibility of a long run equilibrium. They, however, breakdown when there is a mixture of both $I(0)$ and $I(1)$ variables in a model. To deal with this peculiar outcome, the bounds testing approach to cointegration, as proposed by Pesaran and Shin (1998) and Pesaran et al (2001) is appropriate. The test is also efficient for small sample size. The bounds test is incorporated within the autoregressive distributed lag (ARDL) model. It is also advantageous as it simultaneously estimates both the long run and short run parameters. 
According to Pesaran et al (2001), the bounds test cointegration approach is preceded by estimating the unrestricted error correction model (UECM) in equation (8).

$$
\Delta y_{t}=\alpha_{0}+\pi_{i} Y_{t-1}+{ }_{t}+\sum_{i=1}^{p} \vartheta_{i} \Delta Y_{t-j}+\varepsilon_{t}
$$

$Y_{t}$ serves as the vector of all the variables in the model, while $\Delta$ is the first difference operator, the constant term is denoted by $\alpha_{0}$. Lastly, $\pi_{i}$ and $\vartheta_{i}$ are the vectors of the long run multiplier coefficients and the short run dynamic coefficients, respectively. Incorporating our variables into this model, leads to equation (9)

$$
\begin{gathered}
\Delta \ln I N T_{t}=\alpha_{0}+\pi_{1} \ln I N T_{t-1}+\pi_{2} \ln E R S_{t-1}+\pi_{3} \ln M I_{t-1}+\pi_{4} \ln C M_{t-1} \\
+\pi_{5} \ln R E S_{t-1}+\sum_{i=1}^{p} \vartheta_{1} \Delta \ln I N T_{t-i}+\sum_{i=0}^{p} \vartheta_{2} \Delta \ln E R S_{t-i} \\
+\sum_{i=0}^{p} \vartheta_{3} \Delta \ln M I_{t-i}+\sum_{i=0}^{p} \vartheta_{4} \Delta \ln C M_{t-i}+\sum_{i=0}^{p} \vartheta_{5} \Delta \ln R E S_{t-i}+\varepsilon_{t}
\end{gathered}
$$

The bounds test cointegration conclusion is arrived at using the F-test of joint significance on the null hypothesis given as $H_{0}: \pi_{1}=\pi_{2}=\pi_{3}=\pi_{4}=\pi_{5}=0$ against the alternative hypothesis $H_{1}: \pi_{1} \neq \pi_{2} \neq \pi_{3} \neq \pi_{4} \neq \pi_{5} \neq 0$. Bounds test results presents two critical bounds, the upper bound and the lower bound. The null hypothesis of no cointegration is rejected in favour of the alternative hypothesis if the F-statistics is above the upper bounds critical value, thus concluding the existence of long run relationship. If the F-statistics is lower than the lower bound critical value, the hypothesis of no cointegration is accepted and thus the conclusion that no cointegration exists. The decision is inconclusive if the F-statistics lies between these two critical bounds.

\section{Long run and Short run ARDL Estimation}

The next step of procedure in the ARDL bounds test approach is the long run and short run estimation, which is carried out simultaneously by the estimator. This is, however, carried out on the parsimonious model. The long run ARDL in our 
case is given in equation 10 .

$$
\begin{aligned}
\ln I N T_{t}=\vartheta_{0} & +\sum_{i=1}^{p} \vartheta_{1} \Delta \ln I N T_{t-i}+\sum_{i=0}^{p} \vartheta_{2} \Delta \ln E R S_{t-i}+\sum_{i=0}^{p} \vartheta_{3} \Delta \ln M I_{t-i} \\
& +\sum_{i=0}^{p} \vartheta_{4} \Delta \ln C M_{t-i}+\sum_{i=0}^{p} \vartheta_{5} \Delta \ln R E S_{t-i}+\varepsilon_{t}
\end{aligned}
$$

The error correction term (ECT), embedded in the short run dynamic ARDL is given in equation 11.

$$
\begin{aligned}
\Delta \ln I N T_{t} & =\vartheta_{0}+\sum_{i=1}^{p} \vartheta_{1} \Delta \ln I N T_{t-i}+\sum_{i=0}^{p} \vartheta_{2} \Delta \ln E R S_{t-i}+\sum_{i=0}^{p} \vartheta_{3} \Delta \ln M I_{t-i} \\
& +\sum_{i=0}^{p} \vartheta_{4} \Delta \ln C M_{t-i}+\sum_{i=0}^{p} \vartheta_{5} \Delta \ln R E S_{t-i}+\varphi E C T_{t-1}+\mu_{t} \varepsilon_{t}
\end{aligned}
$$

The speed of adjustment is measured using the coefficient of the error correction term $\left(\varphi_{i}\right)$. It gives the rate at which interest rate will converge back to equilibrium in the long run following a shock to the system. The model is subjected to a number of important diagnostics test such as the normality, heteroscedasticity, autocorrelation, linearity and stability tests.

\subsection{Data Sources and Measurement}

Quarterly data from 1997Q1 to 2017Q3 was used in this study. The lending rate was used as a proxy for interest rate, while the average of the monthly external reserves served as the surrogate for reserves. The quarterly data for the trilemma indices were built using the index formulae in Aizenman et al (2010). The data used for the study are sourced from the CBN statistical database and the IMF International financial statistics database.

\subsection{Estimation, Results and Discussion}

\subsection{Statistical Properties and Correlation}

Table 1 presents both the statistical properties of the variables, as well as their correlation coefficients. The maximum value of interest rate stood at $26.3 \%$, while its lowest value is $13.86 \%$. The average value of reserves is approximately 26.3 billion dollars, while its minimum and maximum values are approximately 4.8 billion 
dollars and 62.1 billion dollars respectively. The indices of exchange rate stability, monetary independence and capital mobility have their averages to be approximately $0.51,0.58$ and 0.27 respectively. Also, it can be seen that both ERS and MI have been more embraced by Nigeria as suggested by their higher mean and maximum values, in relation to their CM counterpart. The lower panel of the table presents the correlation matrix of the variables, which shows that interest rate is positively correlated with exchange rate stability and monetary independent, while it is negatively correlated with capital mobility and external reserves.

Table 1: Descriptive Statistics and Correlation Matrix

\begin{tabular}{ccccccccc}
\hline VARIABLES & IR & ERS & MI & CM & RES & ERS*RES & MI*RES & CM*RES \\
\hline Mean & 18.399 & 0.507 & 0.587 & 0.274 & 26265.800 & 8413.600 & 7955.300 & 4164.700 \\
Maximum & 26.300 & 0.969 & 0.992 & 0.313 & 62081.900 & 45612.000 & 23955.000 & 17717.000 \\
Minimum & 13.860 & 0.024 & 0.002 & 0.024 & 4772.300 & 58.760 & 228.320 & 215.800 \\
Std. Dev. & 2.490 & 0.149 & 0.346 & 0.058 & 16380.200 & 11547.000 & 8047.900 & 5500.600 \\
Jarque-B & 31.303 & 29.878 & 8.665 & 270.660 & 5.124 & 23.140 & 5.415 & 6.589 \\
P-Value & 0.000 & 0.000 & 0.013 & 0.000 & 0.077 & 0.000 & 0.067 & 0.037 \\
& & & & & & & & \\
IR & 1.000 & & & & & & & \\
ERS & 0.066 & 1.000 & & & & & & \\
MI & 0.450 & -0.132 & 1.000 & & & & & \\
CM & -0.308 & 0.008 & -0.395 & 1.000 & & & & \\
RES & -0.045 & 0.220 & -0.392 & 0.628 & 1.000 & & & \\
ERS*RES & -0.055 & 0.532 & -0.346 & 0.529 & 0.823 & 1.000 & & \\
MI*RES & -0.010 & 0.231 & -0.189 & 0.637 & 0.956 & 0.797 & 1.000 & \\
CM*RES & -0.079 & 0.198 & -0.420 & 0.681 & 0.996 & 0.818 & 0.952 & 1.000 \\
\hline
\end{tabular}

\subsection{Unit roots}

The unit root result is presented in Table 2. In order to account for the possibilities of structural breaks in the quarterly series, the Zivot-Andrews (ZA) structural break unit root test was employed. From the result, exchange rate stability, monetary independence and capital mobility were found to be stationary at levels, while interest rate and reserves are found to be stationary at first difference. Therefore, concluding that there is mixed order of stationarity among the variables employed in the model. This provides a rationale for the use of bounds test cointegration method, as it is the best cointegration option to address mixed order of variables. 
Table 2: Zivot-Andrews (ZA) Structural Break Unit Roots Test Result

\begin{tabular}{|c|c|c|c|c|c|}
\hline \multirow[t]{2}{*}{ Variables } & \multicolumn{2}{|c|}{$Z$ and $A$ test at Level } & \multicolumn{2}{|c|}{$\begin{array}{l}Z \text { and } A \text { test at First } \\
\text { Difference }\end{array}$} & \multirow[t]{2}{*}{ Outcome } \\
\hline & T-Stat & $\begin{array}{l}\text { Break } \\
\text { date }\end{array}$ & T-Stat & $\begin{array}{l}\text { Break } \\
\text { date }\end{array}$ & \\
\hline INT & -4.31 & $2002 Q 3$ & $-9.6690^{\mathrm{b}}$ & 2002Q4 & $\mathrm{I}(1)$ \\
\hline ERS & $-6.4549^{b}$ & $2003 Q 3$ & $-9.0183^{b}$ & $2001 Q^{2}$ & $\mathrm{I}(0)$ \\
\hline MI & $-5.3607^{b}$ & $2011 Q^{3}$ & $-10.1656^{b}$ & $2016 Q 4$ & $\mathrm{I}(0)$ \\
\hline $\mathrm{CM}$ & $-11.5001^{\mathrm{b}}$ & $2001 Q 3$ & $-11.1454^{\mathrm{b}}$ & $2004 Q^{3}$ & $\mathrm{I}(0)$ \\
\hline RES & -2.71 & 2004Q3 & $-7.9156^{\mathrm{b}}$ & $2016 \mathrm{Q} 1$ & $\mathrm{I}(1)$ \\
\hline
\end{tabular}

Notes: b indicates significant at $1 \%$.

\subsection{Cointegration}

The bounds test cointegration result revealed that although not all the variables are stationary, they still exhibit long run co-movement. This conclusion about the existence of long run relationship is supported, as Table 3 shows that the F-statistics exceeds the upper bounds even at $1 \%$ critical value.

Table 3: Bounds test Cointegration result

\begin{tabular}{ccccc}
\hline Estimated Model & \multirow{2}{*}{ Lag Length } & \multirow{2}{*}{ F-Statistics } & \multicolumn{2}{c}{$1 \%$ Critical Value } \\
& & & $\mathrm{I}(0)$ & $\mathrm{I}(1)$ \\
\hline F(INT/ERS,MI,CM,RES) & $(7,1,9,8,0)$ & $8.78^{*}$ & 3.74 & 5.06 \\
\hline * implies significance at $1 \%$. & & & &
\end{tabular}

\subsection{Regression results.}

The long-run result is presented in Table 4, which gives both the direct effects of the explanatory variables on the endogenous variable and at the same time their indirect effects via interactive terms. The baseline equation shows that all the variables have negative effects on interest rate, but only capital mobility happens to be significant at $1 \%$. This outcome suggests that stability of the exchange rate insignificantly helps to reduce interest rate. Interest rate, as a key macroeconomic variable in an open economy is sensitive to money supply. However, over the years in Nigeria, there have been fiscal expansions, thereby expanding the goods market and putting upward pressure on the exchange rate. A monetary commitment to stabilize the exchange rate will catch the attention of arbitrageurs who sell foreign currency in exchange for Naira. This, therefore, will lead to monetary expansion and invariably reduce interest rates. 
Table 4: Long Run Estimates

\begin{tabular}{|c|c|c|c|c|}
\hline Variables & Equa. 1 & Equa. 2 & Equa. 3 & Equa. 4 \\
\hline Constant & $\begin{array}{c}4.8800 \\
(0.0000)^{* * *}\end{array}$ & $\begin{array}{c}2.7869 \\
(0.0000)^{* * *}\end{array}$ & $\begin{array}{c}3.4035 \\
(0.0000)\end{array}$ *** & $\begin{array}{c}3.5396 \\
(0.0000)^{* * *}\end{array}$ \\
\hline ERS & $\begin{array}{l}-0.0536 \\
(0.6586)\end{array}$ & $c_{(0.5032}^{\text {(0.0000) }}$ *** & $\begin{array}{l}-0.1610 \\
(0.2108)\end{array}$ & $\begin{array}{c}0.1351 \\
(0.3302)\end{array}$ \\
\hline MI & $\begin{array}{c}-0.0704 \\
(0.5023)\end{array}$ & $\begin{array}{l}-0.0674 \\
(0.4325)\end{array}$ & $\begin{array}{c}4.0798 \\
(0.0000)\end{array}$ & $\begin{array}{c}-0.0834 \\
(0.2494)\end{array}$ \\
\hline $\mathrm{CM}$ & $\frac{-4.5591}{(0.0029)}^{* * *}$ & $\begin{array}{l}-0.8816 \\
(0.5383)\end{array}$ & $\frac{-1.6987}{(0.0036)}{ }^{* * *}$ & $\begin{array}{c}5.3426 \\
(0.1673)\end{array}$ \\
\hline RES & $\begin{array}{r}-0.0210 \\
(0.5907)\end{array}$ & & & \\
\hline ERS*RES & & $\frac{-0.3019}{(0.0005)}^{\text {*** }}$ & & \\
\hline $\mathrm{MI}^{*}$ RES & & & $\left.{ }^{-0.1378}{ }^{(0.0000)}\right)^{* * *}$ & \\
\hline $\mathrm{CM}^{*} \mathrm{RES}$ & & & & $\frac{-0.2641}{(0.0213)}$ ** \\
\hline
\end{tabular}

The monetary system in Nigeria has a key goal of maintaining financial stability in the nation. It can thus be inferred that the monetary authorities have keen interest in mopping up excess liquidity from the financial system through contractionary monetary policy. Therefore, a consistent pursuit of this goal might have the resultant effect of pushing down interest rates, leading to a negative impact of monetary independence on interest rate. This train of event is confirmed in our result which shows that, interest rate falls approximately by $0.1 \%$ as a result of a $1 \%$ rise in central bank's independence. Thus supporting that interest rate can be tied to the level of the central bank's independence. However, this effect is not significant, on the other hand, the result shows that increased capital openness has significant inverse effect on interest rates. In agreement with theoretical postulations, expansion of the financial boundaries increases the flow of funds, and invariably local money supply, thereby pushing down interest rates, and vice versa. External reserves also have insignificant negative effects on interest rate, showing that it solely cannot significantly influence interest rates without the contribution of some other relevant variables through which it becomes effective. 
The results in columns 3 to 5 show how external reserves can serve as a buffer to the trilemma in affecting interest rates. The result shows that although exchange rate stability and external reserves do not significantly affect interest rate individually, their interactive form does. This implies that external reserves can serve as a successful buffer for exchange rate stability, to reduce the rate of interest. In the process of stabilizing the exchange rate of Naira, policy makers can harness the potential of a robust international reserves to buy and sell both local and foreign currency, and by so doing, they can effectively drive down interest rates, increase investment and attain increased output. Our results are also indicative of the fact that the independence of the monetary policy makers, having external reserves at their disposal, can be deployed to successfully reduce interest rates. In addition, the interaction coefficient of capital mobility and external reserves shows that they give a negative effect, and at the same time successfully result to reduction in interest rates.

In the long run, we can deduce from the results that, the nation's monetary independence path, amongst other policies, has been able to influence interest rate significantly. Additionally, external reserves have acted, as a buffer for exchange rate stability, monetary independence and capital mobility, in lowering interest rates. Also, the implication of the resultant low interest rate is that investments and output are likely to increase. Therefore, the Central Bank of Nigeria (CBN), which is the apex monetary policy maker in the country, through its independence and regulations can reduce interest rate by maximising the use of international reserves as a tool for macroeconomic stability.

The short run result is presented in Table 5. The result depicts that the trilemma policies do not seem to affect interest rate in the short run as much as the long run, as it is expected that it takes a reasonably time period before a monetary policy can reflect in its targets. Thus, this suggests that the long run effect of the trilemma policies tends to be more effective and produces more significant effect than the short run. The results revealed that, in addition to capital mobility's significant impact on interest rate, its interaction with reserves also does at $5 \%$ 
significance level. This means that capital mobility can be buffered with external reserves to bring down rate of interest in the short run. Also, in the baseline model, the error correction term happens to be negative, less than one and significant, which fulfils the sufficient condition for the error correction terms. The coefficient is approximately -0.31 , meaning that about $31 \%$ of disequilibrium is corrected within the first quarter, showing that a full convergence to equilibrium will be covered within four quarters. In other words, trilemma disequilibrium, from any of the policies and external reserves, will cause disequilibrium in the short-run, but full restoration to normalcy is assured by the end of the fourth quarter.

Table 5: Short Run Estimates

\begin{tabular}{|c|c|c|c|c|}
\hline Variables & Equa. 1 & Equa. 2 & Equa. 3 & Equa. 4 \\
\hline$\Delta \mathrm{ers}$ & $\begin{array}{l}-0.0166 \\
(0.6560)\end{array}$ & $\begin{array}{c}4.0502 \\
(0.1030)\end{array}$ & $\begin{array}{l}-0.0269 \\
(0.5822)\end{array}$ & $\begin{array}{c}-0.0330 \\
(0.3954)\end{array}$ \\
\hline$\Delta \mathrm{mi}$ & $\begin{array}{l}-0.0278 \\
(0.1002)\end{array}$ & ${ }^{-0.0613}(0.0088)^{* * *}$ & $\begin{array}{c}2.6133 \\
(0.0176)\end{array}$ ** & $\frac{-0.0326}{(0.0377)}{ }^{* *}$ \\
\hline$\Delta \mathrm{cm}$ & $\begin{array}{l}-0.3564 \\
(0.5756)\end{array}$ & $\begin{array}{c}7.6107 \\
(0.0075)^{\text {*** }}\end{array}$ & $\begin{array}{c}1.6281 \\
(0.0762)\end{array} *$ & $\begin{array}{c}2.3135 \\
(0.2064)\end{array}$ \\
\hline$\Delta$ res & $\begin{array}{l}-0.0065 \\
(0.6145)\end{array}$ & & & \\
\hline ECT & $\frac{-0.3092}{(0.0002)}^{* * *}$ & $\frac{-0.6935}{(0.0006)}^{* * *}$ & $\frac{-0.7822}{(0.0000)}^{* * *}$ & $\frac{-0.4330}{(0.0000)}^{* * *}$ \\
\hline$\triangle$ ERS $^{*}$ RES & & $\begin{array}{l}-0.1372 \\
(0.1077)\end{array}$ & & \\
\hline$\Delta \mathrm{MI}^{*} \mathrm{RES}$ & & & $\begin{array}{l}-0.0903 \\
(0.0163)^{* *}\end{array}$ & \\
\hline$\Delta \mathrm{CM}^{*} \mathrm{RES}$ & & & & $\begin{array}{l}-0.0775 \\
(0.2424)\end{array}$ \\
\hline
\end{tabular}

\subsection{Diagnostics}

We validated the estimated result by subjecting our baseline model to relevant diagnostics tests, which are reported in Table 6. As presented in the table, the tstats show that the evidence of serial correlation and heteroscedasticity is absent in our model. In addition, the p-values of the normality test, shows that the normality condition of the residuals is fulfilled. At the same time, the Ramsey RESET test results confirmed that the model is correctly specified. Stability of the parameters 
is also confirmed using the CUSUM and CUSUM of squares (CUSUMSQ) tests. The results, as depicted in Figures 9 and 10, show that the estimated relationships are stable since both graphs lie within the $5 \%$ critical bounds.

Table 6: Diagnostics Test Results

\begin{tabular}{ccccc}
\hline Model & $\begin{array}{c}\text { Serial } \\
\text { Correlation }\end{array}$ & BPG Hete Test & Normality Test & $\begin{array}{c}\text { Ramsey RESET } \\
\text { Test }\end{array}$ \\
\hline 1.4811 & 0.9768 & 1.4785 & 0.0144 \\
$(0.19)$ & $(0.51)$ & $(0.46)$ & $(0.91)$ \\
\hline
\end{tabular}

F-statistics are reported, while the p-values are in parenthesis.

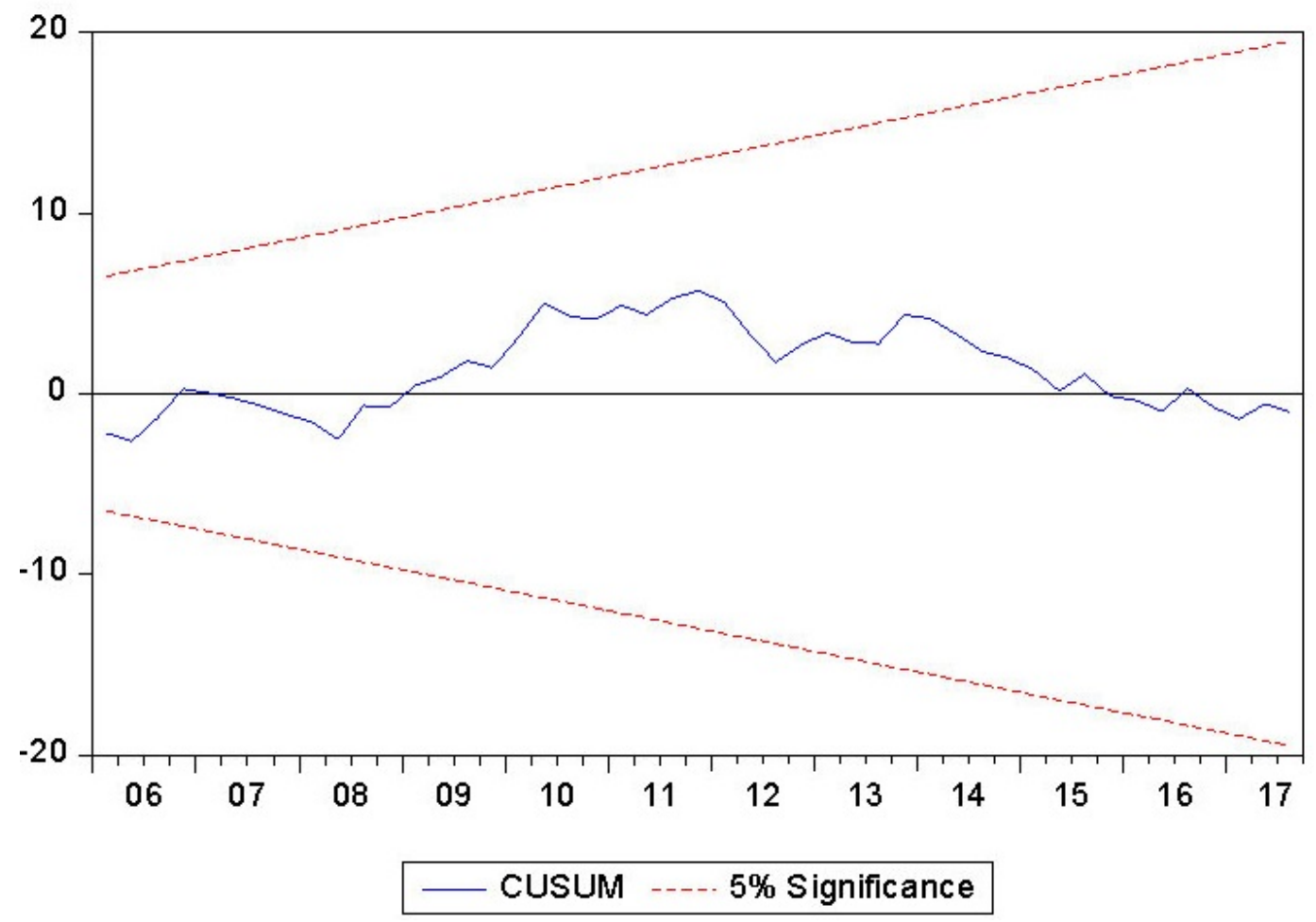

Figure 1: CUSUM 


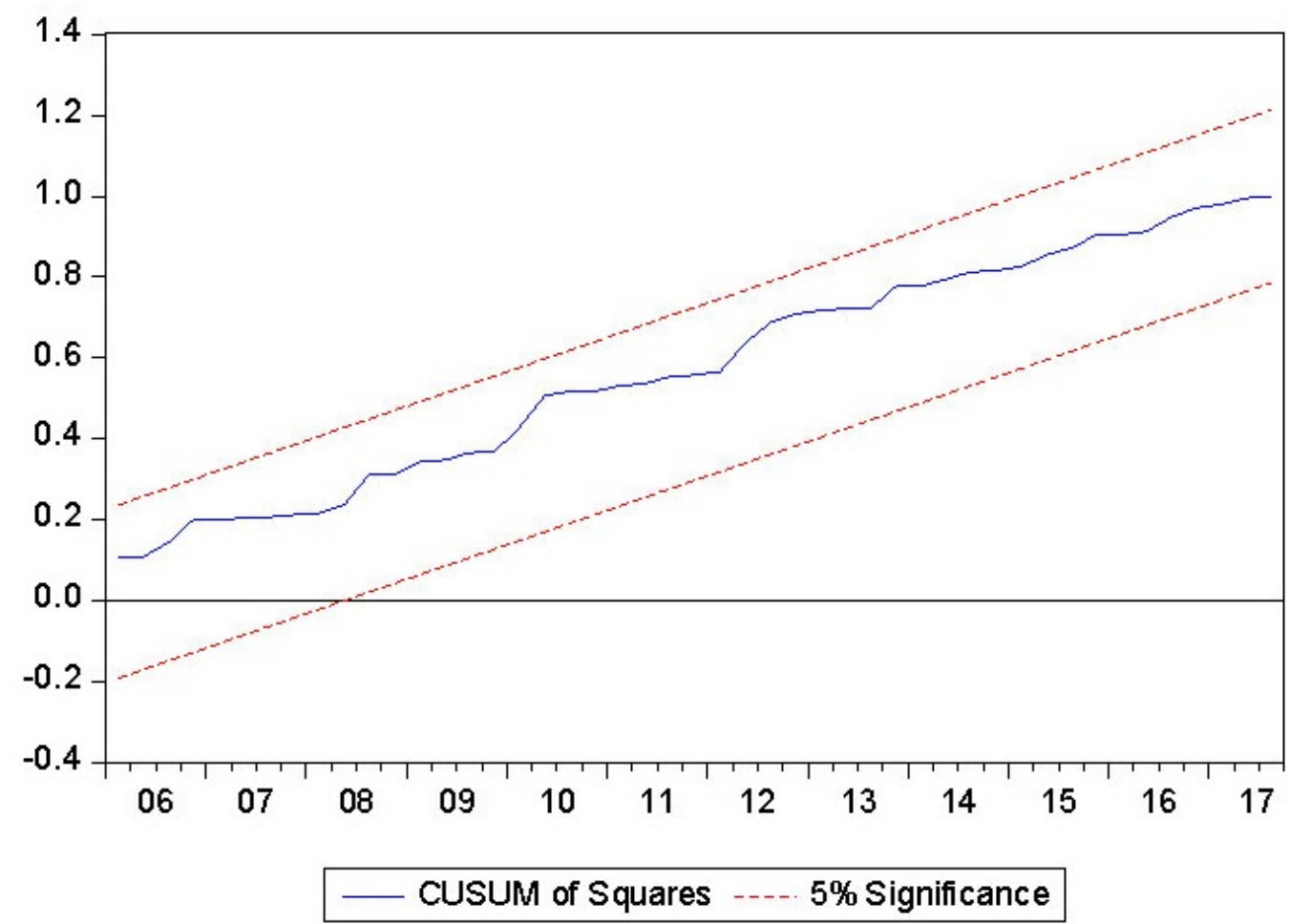

Figure 2: CUSUM SQ

\subsection{Conclusion and Policy Implications}

This study examined the impact of Nigeria's trilemma policy path on interest rate in Nigeria. It further investigated how international reserves can serve as a buffer for the trilemma. The data used spanned from 1997Q1 to 2017Q3. The data was sourced from the IMF's International financial statistics and Central Bank of Nigeria database. The data for our quarterly trilemma indices were arrived at using the index formulae given in Chin and Ito (2008) and Aizenman et al (2010). The Zivot-Andrew unit root test was employed to ascertain the stationarity properties of the variables. The results showed mixed order of integration of the variables. Going further, the ARDL bounds test approach was employed and it ascertained the existence of long run relationship among our variables. We then estimated the long run and short run parameters in our baseline model as well as three other models that accounted for interaction of reserves and each of the trilemma policy variables. 
Our findings revealed that all the indices have negative effect on interest rate. In the interactive models, we found that although exchange rate stability and international reserves do not independently affect interest rate, their interactions can successfully reduce the rate of interest in the economy and thereby plausibly trigger growth through investment. This implies that international reserves can serve as a successful buffer for exchange rate stability. The result holds true for monetary independence which can also be buffered with international reserves to successfully reduce interest rate, both in the long run and in the short run. In addition, the interaction of capital mobility and international reserves can successfully achieve a reduction in interest rate in the long run, but not in the short run. The result also broadly indicated that in the case of disequilibrium, full adjustment back to equilibrium is attained within four quarters.

A number of policy implications can be deduced from these findings. First, the trilemma policy can be used in optimal level to successfully reduce the rate of interest, boost investment and serve as growth-enhancing policy tools if well managed by policy makers. In addition, although external reserves can be used as a tool for economic stabilization, it cannot solely perform this function without appropriately interacting with other relevant policy variables. Thus, in relation to the trilemma policies, the economy can benefit from external reserves if appropriately employed by monetary authorities in proper combination with exchange rate stability and capital mobility. Ultimately, as progress continues with data availability, more related studies will become handy to juxtapose with our conclusions in this paper.

\section{References}

Aizenman, J. (2013). The impossible trinity - from the policy trilemma to the policy quadrilemma. Global Journal of Economics, Vol. 2 No. 01, 1350001.1350001. doi:10.1142/s2251361213500018.

Aizenman, J., and Ito, H. (2012). Trilemma policy convergence patterns and output volatility. The North American Journal of Economics and Finance, Vol. 23 No. 3, pp. 269-285. 
Aizenman, J., Chinn, M and Ito, H. (2009). The emerging global financial architecture: Tracing and evaluating new patterns of the trilemma configuration. Journal of International Money and Finance, Vol. 29 No. 4, pp. 615-641.

Aizenman, J., Chinn, M. D., and Ito, H. (2008). Assessing the emerging global financial architecture: Measuring the trilemma's configurations over time. NBER working paper series, Working Paper 14533.

Aizenman, J., Chinn, M. D., and Ito, H. (2010). Notes on the trilemma measures.

Akinkunmi, M. A. (2017). Empirical analysis of trilemma in emerging economies. Asian Development Policy Review, Vol. 5 No. 4, pp. 199-212.

De Mendonça, H. F., and da Silva V., I. (2017). The open economy trilemma in Latin America: a three-decade analysis. International Finance, Vol. 20 No. 2, pp. 135-154.

Glick. R. and Hutchison. M. (2008). Navigating the trilemma: Capital flows and monetary policy in China. Federal Reserve Bank of San Francisco working paper series.

Herwartz, H., and Roestel, J. (2017). Mundell's trilemma: Policy trade-offs within the middle ground. Journal of International Money and Finance, Vol. 75 , pp. 1-13

Hosny. A. S., Kishor. N. K., and Bahmani-Oskooee. M. (2015). Understanding the dynamics of the macroeconomic trilemma. International Review of Applied Economics. Vol. 29 No.1, pp. 32-64, DOI: 10.1080/02692171.2014.933788

Hsing, Y. (2012). Effects of the trilemma policies on inflation, growth and volatility in Bulgaria. Theoretical and Applied Economics. pp. 49-58.

Ihnatov. I and Capraru. B. (2014). The trilemma policies and macroeconomic volatility in Central and Eastern Europe. Procedia Economics and Finance, Vol. 15 , pp. $853-857$

Ito. H., and Kawai. M. (2014). Determinants of the trilemma policy combination. Asian Development Bank Institute working paper series. No. 456

Law, C. H. (2017). International reserves and trilemma policy convergence in Malaysia. Applied Economics Letters, pp. 1-4

Majumder, S. B., and Nag, R. N. (2017). Policy trilemma in India: Exchange rate stability, independent monetary policy and capital account openness. Global Economy Journal, Vol. 17 No. 3

Mankiw, G. (2010). Macroeconomics. Seventh edition. Worth Publishers. 
Obstfeld, M., Shambaugh, J. C. and Taylor A. M. (2004). Monetary sovereignty, exchange rates, and capital controls: the trilemma in the interwar period. International Monetary Fund staff papers. Vol. 51, (special issue)

Obstfeld, M., Shambaugh, J. C. and Taylor, A. M. (2010). Financial stability, the trilemma, and international reserves. American Economic Journal: Macroeconomics, Vol. 2, pp. 57-94

Obstfeld, M., Shambaugh, J. C. and Taylor. A. M. (2004). The trilemma in history: Trade-offs among exchange rates, monetary policies, and capital mobility. Review of Economics and Statistics, Vol. 87, pp. 423-438

Obstfeld. M. (2014). Trilemma and tradeoffs: Living with financial globalization. Asian Monetary Forum, Singapore.

Pesaran, M. H., and Shin, Y. (1998). An autoregressive distributed-lag modeling approach to cointegration analysis. Econometric Society Monographs, Vol.31, pp. $371-413$.

Pesaran, M. H., Shin, Y. and Smith, R. (2001). Bounds testing approaches to the analysis of level relationships. Journal of Applied Econometrics, Vol. 16, pp. 289-326.

Pilbeam, K. (2006). International finance. Third edition. Palgrave Macmillan.

Prasad, E. S., Rogoff, K., Wei, S. J. and Kose, M. A. (2003). Effects of financial globalization on developing countries: Some empirical evidence. IMF Occasional Paper 220.

Shambaugh, J. C. (2003). The effect of fixed exchange rates on monetary policy. Quarterly Journal of Economics, Vol. 119, pp. 301-352

\section{APPENDIX A}

\section{Exchange Rate Stability (ERS)}

The annual standard deviation of the monthly exchange rate between the home and base country was used to measure the exchange rate stability. The exchange rate stability indices are also normalised between 0 and 1 , higher value indicating more stable movement of the exchange rate against the currency of the base country.

$$
E R S=\frac{0.01}{0.01+\operatorname{stdev}(\Delta \log (\text { exch_rate }))}
$$


According to Aizenman et al. (2010) direct application of this formula can create a downward bias for the index, thus exaggerating the exchange rate flexibility. To avoid such, a threshold of exchange rate movement was done within $+/-0.33$ per cent. That is, if the monthly change in the exchange rate stayed within the $+/-0.33$ per cent bands, the exchange rate is considered to be fixed, and the value of one is assigned for the exchange rate stability index. The authors also dropped single year pegs, as they are reckoned to be quite possibly unintended.

\section{Monetary Independence (MI)}

The indices of the monetary independence are arrived at by taking the reciprocal of the annual correlation of the monthly interest rates of the home country and the base country. The base country is defined as the country that a nation's monetary policy is mostly linked to, just as in Shambaugh (2003). The base country of Nigeria is thus the United States of America (U.S.A). The money market interest rate is used to arrive at the monetary index below:

$$
M I=1-\frac{\operatorname{corr}\left(i_{i}, i_{j}\right)-(-1)}{1-(-1)}
$$

where $i$ represents the home country and $j$ refers to the base country. By construction, the maximum value is 1 , while the minimum value is 0 . The closer the monetary index value is to 1 , the more the monetary policy independence, while the more it is close to 0 , the less is the monetary policy independence.

\section{Capital Mobility (CM)}

This measure is based on the information contained in the Annual Report on Exchange Arrangements and Exchange Restrictions (AREAER) of the International Monetary Fund (IMF). As with the exchange rate stability and the monetary independence, this index is also normalised between 0 and 1 . Higher values indicate that the country is more open to cross-border capital transactions, while lower values suggest that the country is more closed to such capital flows. 